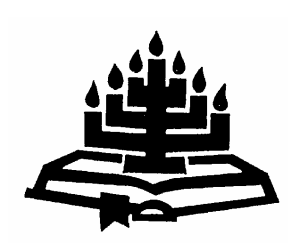

\title{
Christian identity and church unity ${ }^{1}$
}

\author{
C.F.C. Coetzee \\ School of Ecclesiastical Sciences \\ Potchefstroom Campus \\ North-West University \\ POTCHEFSTROOM
}

E-mail: kwscfcc@puk.ac.za

\begin{abstract}
Christian identity and church unity

After centuries of Christianity the theme of "Christian identity" is still relevant and even more diverse than ever before. In this article this theme is discussed from a Reformed perspective with the focus on a specific ecclesiological facet, that is, the viewpoint of church unity. Christian identity has to do with faith in Christ and a specific view of Scripture - a point of departure as manifested in confessional unity. In accordance with this viewpoint the issue of church unity cannot be discussed without taking into account one's presuppositions as found in Scripture and the Reformed Confessions. In order to fulfil our calling as churches in obedience to the "last will" of our Lord (John 17), the Confessions should function as the living belief of the churches, and we should strive and pray untiringly for the unity of the church.
\end{abstract}

\section{Opsomming}

\section{Christelike identiteit en kerkeenheid}

Na eeue van Christendom is die tema van Christelike identiteit steeds aktueel en ook meer divers as ooit tevore. In hierdie artikel word die tema behandel vanuit die Reformatoriese perspektief en met die klem op 'n bepaalde ekklesiologiese aspek, naamlik dié van kerkeenheid. Christelike identiteit hang ten nouste saam met die geloof in Christus en met ' $n$ bepaalde Skrifbeskouing, en hierdie vertrekpunt word gemanifesteer in

1 Reworked version of a paper delivered at the international conference of IRTI held in Seoul, Korea, 5 to 10 July 2005. 
konfessionele eenheid. In ooreenstemming met hierdie uitgangspunt kan die kwessie van kerkeenheid nie bespreek word sonder dat die vertrekpunt soos dit gevind word in die Skrif en die gereformeerde konfessies, in ag geneem word nie. Ten einde ons roeping tot kerkeenheid te vervul, in ooreenstemming met die gebed van Christus self in Johannes 17, moet die belydenisskrifte die lewende besit van die kerk wees en moet ons onvermoeid bid en werk vir ware Skriftuurlike eenheid.

\section{Introduction}

It is significant that after centuries of Christianity, as well as considerable research and discussion on the issue of Christian identity, this theme is still relevant today. Has the interest in this theme continued because the final word has not been spoken? Naude (2003a:437) states that it seems to be a typical Reformed feature to constantly ask questions concerning identity. Could this kind of questions be ascribed to Christianity experiencing an identity crisis? Almost twenty years ago Duquoc (1988a:xix) remarked that "Christians are uncertain about their identity" and continued:

This is not an easy problem. Should one opt for perfect integration in a group with structure, ideology and dynamics which decide what one is; or should one opt for self-definition, only to risk uncertainty about what enables one to say one is a Christian anyway?

The theme of Christian identity can not only be discussed from many angles, but it also has many facets. ${ }^{2}$

It is the aim of this article to look at Christian identity from a Reformed perspective, and furthermore to focus on a specific ecclesiological facet, namely that of church unity. ${ }^{3}$

2 Cf. Van Wyk's article (2004) on Augustine. Holder (2004:265) mentions the fact that within Calvinism as transplanted to America by the Puritans, characteristics like generosity, liberality, morality and a basic humility can be traced. These characteristics have been reflected in the doctrine of total depravity. He continues to refer to another aspect of our "Calvinian legacy", that is, the "pursuit of the godly commonwealth encompassing every dimension of a community's life that in Calvin's mind gave the highest dignity to the vocation of councilors ..." In this respect we have a specific identity that is reflected in the community, the state, etcetera.

3 If Christian identity is understood as the Calvinistic-Reformed tradition as it culminated in the Confessions of the Reformed churches, it has implications for 


\section{Defining Christian identity}

As Reformed churches we confess that we are called Christians because we are members of Christ by faith. In Christ we partake of His anointing with the Holy Spirit on the following grounds (cf. Heidelberg Catechism, answer 32):

- We may openly confess His Name;

- We may present ourselves as living sacrifices of thankfulness to Him;

- We may fight against sin and the devil in this life with a free and good conscience;

- Hereafter we shall reign with Him eternally over all creatures

In spite of this clear definition, however, many people who call themselves Christians do not live according to this confession. The name "Christian" nowadays implies many meanings and is defined very broadly.

The same is true for the ecclesiological definition of Christianity. Christianity has many faces. From an ecclesiastical point of view one finds different kinds of identities: the identity of the so-called main-line churches, the charismatic movement, and that of Roman Catholicism, apart from new identities being formed, such as that of the Dutch "Protestantse Kerk Nederland" (cf. Van Wyk 2005:4), to name just a few. Some people could conclude that diversity, pluriformity and dissension can be regarded as aspects associated with Christianity. Berkouwer (1970:31) focuses on the unity and division of the church in the same chapter. On the one hand we therefore agree with Blei (1993:3) that we should not try to identify a specific Protestant or even a specific Reformed identity. Our main concern should not be to outline Reformed identity but rather to highlight "Christian identity". On the other hand it is necessary to qualify the term.

From a biblically founded point of view the identity of a Christian cannot be separated from his/her faith in Christ. "Christian identity is the adventure of a meeting with Jesus Christ, of a life shared with Him on the path which leads Him to the Cross" (Bühler, 1988:26). This identity also concerns one's view of Scripture. 
If something exists like a 'Reformation identity', then it consists of the unconditional recognition of God's Word that through scripture creates communities and in these addresses individuals to guide and redeem them (Eicher, 1988:88).

An essential part of a Calvinist's identity is the acceptance of Scriptura tota as well as Scriptura sola (Palmer, 1980: Foreword; cf. also Van Wyk, 1995:248). Naude (2003a:446) also emphasises this point of departure when he says: "One does not have to argue the point that the heart of our Reformed identity is the centrality of the Word of God in its various manifestations."

Ultimately Christian identity as seen and qualified from a Reformed perspective is manifested in confessional unity. In this regard it is important to take note of the following statement by Trueman (2004:225):

... it is too often assumed that Calvin's theology has, or had at some point in the past, some kind of normative status within the Reformed tradition. This is historically and ecclesiastically not so .... The historic identity of Reformed Theology has always been expressed through public confessional documents such as the First and Second Helvetic Confessions, the Consensus Tigurinus, the Heidelberg Catechism, the Belgic Confession, the Canons of Dordt and the Westminster Standards.

The view exists that in the current postmodern age something like "Reformed identity" is neither intelligible nor defensible (Stroup, 2003:258). Another view implies that we should strive towards a "collective identity" in which "conservatives" and "liberals" with radically different viewpoints on the authority of Scripture, the historical Jesus, and other central doctrines can make room for one another (Landman, 2005:12). There is even a viewpoint that Christianity "has to vanish as an external phenomenon, as indeed a church" (Duquoc, 1988b:117). And then there is the viewpoint that "doctrine divides, service unites" (Jesson, 2003:1). From a Reformed point of view, however, it can be stated that identity and doctrine or identity and confession cannot be separated.

In this regard scholars are found who are of the opinion that it is actually impossible "to define a common Reformed identity by means of the confessional tradition of Reformed Churches" (Ernst, 2003:86). Ernst (2003:86) also refers to the many new confessions coming into being in our days - a view shared by Stroup (2003:258). 
In opposition to the viewpoint of Ernst it can be argued that it is not the number of confessions that matters. In the time of the sixteenthcentury Reformation many confessions were written. The decisive question is whether the different confessions contradict one another or whether every confession is in accordance with Scripture (homologia).

A number of scholars emphasise the necessity of confessional unity in order to establish a specific Christian identity. Stroup (2003:260) thus states: "The confessions are the church's identity documents." Ernst (2003:87) admits that many theologians, as well as Reformed churches and the World Alliance of Reformed Churches have struggled for quite a time to define what specific quality can be regarded as "Reformed", and what inherent characteristics distinguish the Reformed tradition from other Christian traditions. In this regard confessions hold a special authority (Ernst, 2003:88). "All other expressions of the faith and life of Reformed Churches can also be considered and fully understood in their relation to the insights of faith that are expressed in confessional statements" (Ernst, 2003:88). Confessions articulate in a distinctive way the living faith of a church, and they are guidelines for the expression of the faith of that specific church. In this respect confessions also have an apologetic function. Their purpose is to draw a distinct line between Scriptural truth and heresy.

It may therefore happen, and indeed it happens, that confessions play a role in keeping Christians and Christian groups apart. This is to a certain extent the case with the Belhar Confession in the family of the Dutch Reformed Church in South Africa (cf. Jackson, 2005). De Gruchy (2004:17) also argues that an orthodox Calvinist insistence on a creed as a basis for the unity of the church usually results in the disunity of the church. Nevertheless, from a Reformed perspective it must be clear that a true biblically founded Christian identity cannot be defined without taking into consideration the Confessions of the family of Reformed churches.

\section{The unity of the church}

The sixteenth-century Reformer Martin Bucer called this unity "the most necessary thing" (cf. Payton, 1992:38). Bucer made this statement in the midst of the controversy regarding Holy Communion. In the Nicene creed (A.D. 381) we confess that we believe in the one, holy, catholic and apostolic church (unam sanctam catholicam et apostolicam). After so many centuries this creed still forms the basis for discussions on the unity of the church 
and the founding of ecumenical movements (cf. Jesson, 2003:8, 12, $13,19,20$ with reference to the WCC). Naude (2003b:1) points out that the important issue of some agreement on the "essentials" of the Christian faith have been part of the contemporary ecumenical movement from its beginning. "With the formation of the World Council of Churches in 1948 in Amsterdam, 'the visible unity of the church in one faith and in one eucharistic fellowship', emerged as the ultimate aim of the new organization" Naude (2003b:1) It is evident that Naude has the Nicean Creed in mind as part of the "essentials" of the Christian faith, since he continues to draw a comparison between Nicea and Belhar. He also points out that it is significant how the Nicene Creed emphasises unity (Naude, 2003b:11).

The confession of the unity of the church is a formulation of the truth of Scripture. That there is only one church is a very clear teaching of Scripture. Berkouwer (1970:34) points out that the issue of the unity of the church has been debated repeatedly. The truth of the unity of the church is, however, more than clear from the New Testament in its totality (Berkouwer, 1970:32, 33). The phrase "the one church" is not found in Scripture, because it would in fact be a pleonasm (Berkouwer, 1970:33). The fact that there can be only one ecclesia excludes the plural by definition (Berkouwer, 1970:34).

Scouteris (1985:401) points out that the early Church Fathers also interpreted the unity in purely biblical and theological terms. The cause or source of this unity is Jesus Christ (cf. inter alia Staton, 1997:291). "There can be unity of the people because there is Christ" (Scouteris, 1985:406). The en Xristooi is therefore the necessary presupposition for the unity of people in the one body of the church (Scouteris, 1985:414). This view of the Lord of the church determines the fact that it is absolutely impossible to replace the singular with the plural (Berkouwer, 1970:47).

The truth that there is only one church also becomes clear from metaphors used in Scripture to indicate the relationship between Christ and his church. According to Berkouwer (1970:47) there can be only one house, as there can be only one bride, one temple, one flock, one body.

The Reformer, John Calvin, said in this regard that "two or three (churches) cannot come into existence without dividing Christ; and this is impossible" (quia non duas aut tres invenire liceat quin discerpatur Christus: quod fieri non potest) (Inst. 4.1.2; O S II, 747). 
The unity of the church must be concomitantly seen from the perspective of the oneness of the triune God. "The Divine oneness is the model for the oneness of the people" (Scouteris, 1985:405; cf. also Staton, 1997:291). According to Naude (2003b:11) the focal point of the unity in the Nicene Creed is the Trinity as representing one God in whose very being Father, Son and Spirit are equally divine and from whose grace the church as one church is established.

In this regard many scholars refer to the prayer of Christ in John 17 (also called his "last will", cf. Käsemann, Jesu letzter Wille) (cf. Scouteris, 1985; Pollard, 1958-1959; Staton, 1997; Payton, 1992; Du Toit, 1977:101; Berkouwer, 1970). With reference to John 17:2124 , it is emphasised that the unity of the church is a unity modelled on the unity (union) between the Father and the Son (Staton, 1997:294). The unity is analogical of the unity between the Father and the Son (Berkouwer, 1970:56). A more convincing indication of unity does not exist. The unity between Father and Son forms the deepest foundation for that which belongs to the essence of the church (Berkouwer, 1970:57).

What is also very important and significant is that the unity of the church is not an isolated matter, but that the whole world is incorporated and implied in John 17:21: "May they also be in us so that the world may believe that you have sent me" and also in verse 23: "May they be brought to complete unity to let the world know that you sent me and have loved them even as you have loved me" (cf. Berkouwer, 1970:51). In these verses not only the missiological calling of the church but also the whole issue of identity comes to the fore. The unity must be seen. The world must see the church in her unity as a letter of Christ (1 Cor. 3:2; cf. Berkouwer, 1970:51).

Furthermore the unity of the church must and can only be a unity in truth. Christ also prayed that his church should be protected from the evil one and might be sanctified in the truth of his Word (John. 17:15, 17). The truth that Christ gathers, defends, and preserves his church through His Spirit and Word, and in the unity of the true faith, is also confessed in the Heidelberg Catechism, Lord's day 21. The implication of this prayer is that any search for unity that conceals the truth is not in accordance with the prayer of the Lord (Du Toit, 1977:101). Those who do not love the truth above all, can not make an appeal to John 17 (Du Toit, 1977:101). What really matters when it comes to unity as mentioned in John 17, is the Word (John 17:13), the Truth (John 17:19) and the Name (John 17:26) (see Berkouwer, 1970:56, with reference to Käsemann). 
The unity of the church is a unity in diversity. The diversity should, however, consist of a diversity including "non-theological factors", like language, culture, and so on (Naude, 2003a:436, 437). It should not be a diversity with regard to matters like for instance homosexuality (cf. De Gruchy, 2004:20). The marks of the church also have ethical dimensions (Jesson, 2003:13). The diversity should also not be a diversity in doctrinal or confessional matters. Unity in truth implies a unity in doctrine and confession.

When the Roman Catholic Church accused Calvin of heresy and of causing schism, he replied as follows:

As to their charge of heresy and schism, because we preach a different doctrine, ... it is indeed a very serious accusation, but one which needs not a long and laboured defence. The name of heretics and schismatics is applied to those who, by dissenting from the Church, destroy its communion. This communion is held together by two chains - viz. consent in sound doctrine and brotherly charity. ... But the thing to be observed is, that this union of charity so depends on unity in faith, as to have in it its beginning, its end, in fine, its only rule.

[Haec porro duobus vinculis continetur, sanae doctrinae consensione et fraterna caritate ... Verum id quoque notandum est, hanc caritatis coniunctionem sic a fidei unitate pendere, ut haec illius initium, finis, unica denique regula esse debeat.

(Inst. 4.2.5; O S II, 771/2; cf. Calvin, 1964)]

It is well known that Calvin strived for the unity of the church more than anyone else. Wendel (1969:311) even calls hom a "champion of church unity". Calvin himself said, "Always, both by word and deed, have I protested how eager I was for unity" (cf. Calvin \& Sadoleto, 1966:86).

It is worth mentioning that Calvin primarily emphasised the Word of God: "... the only thing I asked was that all controversies should be decided by thy Word (cf Calvin \& Sodoleto, 1966:86). Obviously Calvin was not interested in a unity that was not a unity in truth (Calvin, 1953:58; Nijenhuis, 1959:302). It is, however, also important to note that Calvin was opposed to any confessionalism (Nijenhuis, 1959:298-299). He distinguished between matters of fundamental nature and matters of mediocre nature, although this distinction did not lead to confessional indifferentism (cf. Pont, 1995:390-393; Van Wyk, 2005b:188). 


\section{Identity and unity}

According to John 17:21, 23 identity and unity are very closely related. Christ prays for this unity as a "window", and He prays for the transparency of this unity (Berkouwer, 1970:53). What else can be meant by this prayer than identity? Naude (2003a:436) quotes Geoffrey Wainwright on this relationship:

At stake in the understanding of unity and schism, of continuity and discontinuity, of integrity and fragmentation, is precisely the identity of the church and therewith the nature and substance of truth and the conditions of its authoritative expression.

\section{Concluding remarks}

It has been argued that, from a Reformed perspective, the issue of Christian identity as well as the issue of church unity cannot be focused on without taking into account one's presupposition from Scripture and the Reformed Confessions. True Christian identity is determined by one's confessional foundation. True church unity can only be established in the truth of Scripture as formulated in the Reformed Confessions. Although the Reformed tradition is the only tradition in which confessions are found (Naude, 2005:11) this principled viewpoint cannot be compromised, not even in our postmodern age.

Having said this, it must at the same time be admitted that this point of departure does not make a difference to the reality that the church of our times is both one and divided (cf. Berkouwer, 1970:31). In the year 2003 the number of "denominations" was approximately 33 800 , and this number is increasing every day (cf. Van Wyk, 2005:532). Today we experience the unity as well as the disunity of the church. Van Wyk (2005:532) also points out that the church of all ages has struggled with a very difficult dilemma in the ecclesiology: the issue of unity versus holiness, and the issue of catholicity versus apostolicity.

We experience the disunity between churches, religious groups and ecumenical movements from different theological traditions. We, however, also experience the lack of real unity between church communities in the same Reformed tradition. The Belhar Confession has played a significant role in delaying or even preventing the process of unification in the family of Dutch Reformed Churches in South Africa (cf. Jackson, 2005). The three South African Reformed church communities with the same culture and language (Afrikaansspeaking), namely the Dutch Reformed Church, the Nederduitsch 
Hervormde Kerk and the Reformed Churches in South Africa, have since 1958 constantly discussed those matters that keep them apart, and still real unity could not be restored. To my mind one of the main reasons for this tragic situation is the fact that - although these churches adhere (formally?) to the same Reformed Confessions (the three Ecumenical creeds and the Three formulas of unity) - they differ to a smaller or larger extent when it comes to the functioning, implementation and interpretation of these Confessions.

Even an ecumenical movement such as the World Council of Churches with its very broad confessional basis has experienced a separation among its member churches, as Jesson (2003:3, 4) points out.

What is the solution to this tragic phenomenon of separation or division in the church of Christ? Can we just accept that the disunity of the church will be part of this sinful dispensation? In Reformed churches the viewpoint that this phenomenon only demonstrates the pluriformity of the church, has long been rejected.

The solution does not lie in the viewpoint that Christianity is "one way among others" (Duquoc, 1988b:122, 123). The solution that Berkhof proposes (cf. Ernst, 2003:95) that there should be a radical return to the preconfessional and predenominationalist stage of Reformed ecclesiology, is also not the answer. Neither does the solution lie in the forming of a "collective identity" (Landman, 2005:12), nor does Blei's plea for a "pilgrim identity" (Blei, 1993:5) offer the solution. Service alone, without doctrine, will not unite.

In agreementt with Van Wyk (2004:532) we should never stop striving and praying for the unity of the church in accordance with the prayer of our Lord. We should have passion for unity, and then passion kindled by love, keeping in mind what Calvin said about the priority of the unity in faith (Van Wyk, 2005:533).

Snyman $(1977: 110,111)$ discusses the unity of the church in its separation or division. By this is meant that churches that are separated should not stop talking to one another. They should come together in fellowship and seriously discuss the matters that separate them on the basis of Scripture and the Confessions.

In this regard, the three Afrikaans-speaking Reformed church communities, after years of discussion, recently formed a more formal fellowship in a so-called Interdenominational Council. This 
council meets twice a year. On the agenda mainly three points are discussed, namely the joint witness of the churches to the community and the state, the cooperation of the churches in matters like education, the combatting of poverty et cetera, and the critical discussion of doctrinal and other matters that separate these churches. Some of these matters concern the following: the ordaining of women in the offices of minister and elder, the administering of the Lord's Supper to children, the church's viewpoint on homosexuality, liturgical matters, the government of the church, the Belhar confession, et cetera. Ongoing discussion of these matters are of the utmost importance in the process of unification.

If we are serious about our calling to strive and pray for unity, the following factors are fundamental:

- The Confessions should function as the living belief of the churches.

- There should be a clear distinction between mediocre and essential matters. In this regard it is worthwhile to take note of Calvin's viewpoint in his advice to the members of the Stranger Church in London that experienced circumstances different from those in Geneva (cf. Pettegree, 2004:207).

- The untiring continuation of talks on an ecumenical level.

Matthew 12:25 states it very clearly that a household divided against itself will not remain standing. The unity of Christ's church was an essential part of the "last will" of our Lord, because the salvation of so many people in the world is at stake (John 17:21). We have a calling to fulfil this task in obedience, and in the surety of the will of Jesus Christ.

\section{List of references}

ANDREW MURRAY CONGREGATION OF THE DUTCH REFORMED $\mathrm{CHURCH}$. Kensington, Johannesburg. 1986. Doctrinal standards of the Dutch Reformed Church: consisting of the Belgic Confession, the Heidelberg Catechism and the Canons of Dort.

BERKOUWER, G.C. 1970. De kerk: eenheid en katholiciteit. Kampen: Kok. (Dogmatische studiën.)

BLEI, K. 1993. Some Dutch reflections on reformed identity. (In Opocensky, M., Stephens, S., Wilson, H., eds. The reformed world. Geneva: World Alliance of Reformed Churches. p. 2-9.) 
BÜHLER, P. 1988. Christian identity: between objectivity and subjectivity. (In Duquoc, C. \& Floristan, C., eds. Christian identity. [Gardiner, J.A. English language ed.] Edinburgh: Clark. p. 17-27.) (Concilium. Vol. 196, pt. 1. Special column.)

CALVIN, J. 1953. Om de eenheid en vrede der kerk: Johannes Calvijns geschrift. Vera Christianae pacificationis et ecclesiae reformandae ratio. Vertaald naar de Latijnse uitgavan van Baum, Cunitz en Reuss door F.J. de Groot. Amsterdam: Van Bottenburg.

CALVIN, J. 1964. Institutes of the Christian religion. Translated by Henry Beveridge. Grand Rapids: Eerdmans.

CALVINI OPERA OMNIA, i.e., Ioannis Calvini Opera Quae Supersunt Omnia. Vol. I-LIX. Ediderunt G[W] Baum, E. Cunitz \& E. Reuss. Vol. I-LIX. (In Corpus Reformatorum. Vol. XXIX-LXXXVII. Brunsvigae/Berolini, C.A. Schwetschke et filium, 1863-1900. [=CO 1-59].)

DE GRUCHY, S. 2004. Dissenting Calvinism: reflections on the congregational witness in South Africa as part of the wider reformed tradition. Theologia Viatorum: Journal of Theology and Religion in Africa, 28(1):1-23.

DU TOIT, J.D. 1977. Die kerk. Kaapstad: Tafelberg. (Totius versamelde werke, vol. 2.)

DUQUOC, C. 1988a. Editorial. Tr. by J.G. Cumming. (In Duquoc, C. \& Floristan, C., eds. Christian identity. [Gardiner, J.A. English language ed.] Edinburgh: Clark. p. xix-xx.) (Concilium, vol. 196. Special column.)

DUQUOC, C. 1988b. Church membership and Christian identification. (In Duquoc, C. \& Floristan, C., eds. Christian identity. [Gardiner, J.A. English language ed.] Edinburgh: Clark. p. 116-127.) (Concilium, vol. 196, pt. 4. Special column.)

EICHER, P. 1988. The burning bush: Holy Scripture and the reformation question of identity. (In Duquoc, C. \& Floristan, C., eds. Christian identity. [Gardiner, J.A. English language ed.] Edinburgh: Clark. p. 80-92.) (Concilium, vol. 196, pt. 3. Special column.)

ERNST, M. 2003. We believe the one holy and catholic church, reformed identity and the unity of the church. (In Alston, W.M. \& Welker, M., eds. Reformed theology: identity and ecumenicity. Grand Rapids: Eerdmans. p. 85-96.)

HOLDER, R.W. 2004. Calvin's heritage. (In McKim, D.K., ed. The Cambridge companion to John Calvin. Cambridge: Cambridge University Press. p. 245-273.)

JACKSON, N. 2005. Sny bande met VGK, vra NG gemeente: weg met Belhar en ander wat dit aanvaar, lui besluit. Beeld: 31 Mei.

JESSON, N.A. 2003. Doctrine divides, service unites: towards a vital and coherent theology. Toronto: University of St. Michael's College.

LANDMAN, C. 2005. Nuwe speelveld is in kerk moontlik: liberale, behoudendes deel van mekaar se verhaal. Beeld: 12, 13 Jun.

NAUDÉ, P.J. 2003a. Identity and ecumenicity: how we deal theologically with so-called "nontheological" factors? (In Alston, W.M. \& Welker, M., eds. Reformed theology: identity and ecumenicity. Grand Rapids: Eerdmans. p. 435-449.)

NAUDÉ, P.J. 2003b. Confessing the one faith: theological resonance between the Creed of Nicea (325AD) and the Confession of Belhar (1982). (Unpublished paper read at the fifth Ecumenical Forum, Ecumenical Institute at the University of Heidelberg on 11 January 2003.) 
NAUDÉ, PIET. 2005. 10 Stellings oor gereformeerde identiteit. Die Kerkbode, 174(9):10.

PALMER, E.H. 1980. The five points of Calvinism. Enlarged ed. Grand Rapids: Baker Books.

PAYTON, J.R. 1992. On unity and truth: Martin Bucer's sermon on John 17. Calvin Theological Journal, 27(1):26-38.

PETTEGREE, A. 2004. The spread of Calvin's thought. (In McKim D.K., ed. The Cambridge companion to John Calvin. Cambridge: Cambridge University Press. p. 207-224.)

POLLARD, T.E. 1958-1959. "That they all may be one": John xvii.21 and the unity of the church. Expository Times, 17:149-150.

SCOUTERIS, C. 1985. The people of God, its unity and its glory: a discussion of John 17.17-24 in the light of patristic thought. Greek Orthodox Theological Review, 30(4):399-420.

SNYMAN, W.J. 1977. Nuwe en ou dinge: uit die skat van die koninkryk. Versamel en aan hom opgedra deur sy oud-studente by geleentheid van sy sewentigste verjaardag. P.C. Snyman, red. Potchefstroom: Pro Rege. (Raad vir Geesteswetenskaplike Navorsing. Publikasiereeks, 1977:56.)

STATON, J.E. 1997. A vision of unity: Christian unity in the fourth Gospel. Evangelical Quarterly, 69(4):291-305.

STROUP, G.W. 2003. Reformed identity in an ecumenical world. (In Alston, W.M. \& Welker, M., eds. Reformed theology: identity and ecumenicity. Grand Rapids: Eerdmans. p. 257-270.)

TRUEMAN, C.R. 2004. Calvin and Calvinism. (In McKim, D.K., ed. The Cambridge companion to John Calvin. Cambridge: Cambridge University Press. p. 225-244.)

VAN WYK, J.H. 1995. Die relevansie van die gereformeerde teologie vir vandag. In die Skriflig, 29(1-2):241-267.

VAN WYK, J.H. 2004. Christelike identiteit: Augustinus oor geloof, hoop en liefde. In die Skriflig, 38(4):519-536.

VAN WYK, J.H. 2005. Die kerk in Nederland: April 2005. Die Kerkblad, 108(3176):4-5.

WRIGHT, D.F. 2004. Calvin's role in church history. (In McKim, D.K., ed. The Cambridge companion to John Calvin. Cambridge: Cambridge University Press. p. 277-288.)

\section{Kernbegrippe:}

belydenisskrifte

Christelike identiteit

kerkeenheid

Skrifbeskouing

\section{Key concepts:}

Christian identity

church unity

confessions of faith

view of Scripture 
